UDC 536.7

O. Butenko,

V. Demidenko,

O. Brunetkin, DSc, Assoc. Prof.

Odessa National Polytechnic University, 1 Shevchenko Ave., Odessa, Ukraine, 65044; e-mail: butik-tks@ukr.net.

\title{
THE METHOD OF DETERMINING THE COMPOSITION OF HYDROCARBON FUEL BY THE RATIO OF FUEL AND AIR CONSUMPTION AND TEMPERATURE OF COMBUSTION PRODUCTS
}

\begin{abstract}
О.В. Бутенко, В.Е. Демиденко, О.І. Брунеткін. Метод визначення складу вуглеводневого пального по співвідношенню витрат пального і повітря та температурі продуктів згорання. Використання екстремальних регуляторів має загальний недолік, який залежить від виду екстремальної характеристики. При наближенні до точки екстремуму градієнт вимірюваного параметра 3 прийнятою обчислювальною похибкою зменшується до нуля. Таке відбувається, як для випадка визначення максимальної температури при горінні, так і для випадка визначення максимальної температури теплоносія. У ряді випадків з'являється можливість організації процесів управління, які не мають екстремальних характеристик а носять тільки розрахунковий характер по вимірам. Мета наукового дослідження полягає в розробці методу визначення складу вуглеводневого пального по співвідношенню витрат пального і повітря та температурі продуктів згоряння. Наукова і практична значущості роботи полягає в визначені загального типу задачі, як зворотно некоректно поставленої і виділено іії більш вузький клас - складна задача інтерпретації. Розроблено метод заповнення бібліотеки розв'язками прямої задачі у вигляді робочого тривимірного масиву. Для цього запропоновано метод перетворення вихідних даних прямої задачі в число-згортку яке формується на основі позиційного принципу запису десяткових чисел. Методології дослідження базується на методі розв'язання - метод Ньютона-Рафсона, числі обумовленості квадратної матриці та на методі бібліотеки для розв'язання зворотної задачі. Основним результатом запропонованого методу при визначенні складу палива для розглянутих речовин (метан, пропан, етиловий спирт) можна вважати отримане точне рішення в рамках моделі.Практична цінність проведеного дослідження полягає в тому, що показана відсутність похибок, що вносяться до рішення алгоритмом запропонованого методу. Розрахункові похибки обумовлені тільки дискретизацією вихідних даних при розв'язані прямої задачі. Визначено вплив точності вимірювань технологічних параметрів на похибку визначення складу пального.

Ключові слова: вуглеводневе пальне, горіння, пряма задача, метод бібліотеки, число обумовленості квадратної матриці

O. Butenko, $V$. Demidenko, O. Brunetkin. The method of determining the composition of hydrocarbon fuel by the ratio of fuel and air consumption and temperature of combustion products. The use of extreme regulators has a common disadvantage, which depends on the type of extreme characteristic. When approaching the extremum point, the gradient of the measured parameter with the accepted computational error decreases to zero. This happens both for the case of determining the maximum temperature during combustion and for determining the maximum temperature of the coolant. In some cases, it is possible to organize management processes that do not have extreme characteristics but are only calculated in nature. The purpose of the scientific study is to develop a method for determining the composition of hydrocarbon fuel by the ratio of fuel and air consumption and temperature of combustion products. The scientific and practical significance of the work lies in the definition of the general type of problem, as inversely incorrectly assigned and distinguished its narrower class - a difficult task of interpretation. The method of filling the library with direct problem solvers in the form of a working threedimensional array is developed. For this purpose, we propose a method of converting the output of a direct problem into a convolution number that is formed on the basis of the positional principle of writing decimal numbers. The research methodology is based on the solution method (the Newton-Raphson method), the square matrix conditionality, and the library method for solving the inverse problem. The main result of the proposed method in determining the composition of the fuel allowed for the substances (methane, propane, ethyl alcohol) can be considered to be the exact solution within the model. The practical value of the study is that it shows that there are no errors that are contributed to the solution by the algorithm of the proposed method. The calculation errors are only due to the discretization of the source data when solving a direct problem. The influence of measurement accuracy of technological parameters on the uncertainty of fuel composition determination is determined.

Keywords: hydrocarbon fuel, combustion, direct problem, library method, number of square matrix conditionality
\end{abstract}

\section{Introduction}

Currently, there is no single method of optimal control of the combustion process of hydrocarbon gas of unknown composition. This is due to the different uses of the technological product, which is obtained later. This is combustion for energy purposes, use as petrochemical raw materials, or use of the resulting product in metallurgical technology. 


\section{Analysis of recent publications and problem statement}

The use of any type of extreme controllers has the general disadvantage that depends on the type of extreme characteristic. When approaching the extremum point, the gradient of the measured parameter with the accepted computational error decreases to zero. This happens both for the case of determining the maximum temperature during combustion [1] and for the case of determining the maximum temperature of the coolant [2]. A similar property of the gradient of the measured parameter occurs in the case of determining the minimum concentration of carbon monoxide (CO), when the value of the concentration of oxygen in the flue gases approaches zero [3]. Given the sensitivity threshold and errors of the measurement and control systems at the extreme point, large errors occur in determining the magnitude of the search. Measurement channel noise also has a negative effect on the accuracy of determining such a value. As a consequence, a maximum measurement error is formed in the vicinity of the extremum point, which is significantly complicating, and in some cases makes it impossible to use extreme regulators to control the combustion of variable fuel.

You can use gas analyzers to identify components in unknown gas mixtures. In the future, the identified mixtures are used for combustion for energy purposes or the identified components are used for transformation in chemical technologies of hydrocarbon gases. In such cases, it is possible to organize management processes that do not have extreme characteristics. An example would be a nonoxidizing heating furnace [4] or an organic synthesis reactor.

Existing models and methods for determining the composition of the fuel by the measured consumption of it and the air, as well as by the temperature of the combustion products, set out in [5 - 7] allow for the excess measurements of fuel consumption, air and the temperature of the flame, to carry out the correction of the generalized formula of gaseous fuel for compensation for internal and external disturbances. This adjustment allows you to find a stable solution for the fuel-air ratio. The proposed method of determining the variable composition of the fuel allows in real time to ensure the efficient operation of the equipment. The developed model and method of solving the definition of conditional fuel formula is a system of nonlinear algebraic equations. The application of the NewtonRaphson method to determine the temperature of combustion products with a known fuel composition gave a similar solution [5-7].

The problem is that when approaching the extremum point, the gradient of the measured parameter with the accepted computational error decreases to zero. This happens both for the case of determining the maximum temperature during combustion and for determining the maximum temperature of the coolant.

\section{The purpose and objectives of the study}

The purpose of this article is to develop a method for determining the composition of a hydrocarbon fuel by the ratio of fuel to air flow and the temperature of combustion products without a gradient of the measured parameter. The steps of solving such a problem were as follows:

- analysis of the possibility of solving the problem of determining the conditional fuel formula;

- the method of filling the library when solving a direct task;

- modeling of technological measurements without errors.

Analysis of the possibility of solving the problem of determining the conditional fuel formula

An attempt was made to apply the Newton-Raphson method to determine the fuel composition by measured flow and temperature on the basis of the proposed model, but no positive result was obtained. A similar solution for a simpler case of hydrocarbon fuel could not be obtained. In the latter case, methane $\left(\mathrm{CH}_{4}\right)$ was considered as the fuel for modeling. Hydrocarbon fuel is selected due to the coincidence of the composition of the combustion products [5-7] in comparison with the case of combustion of oxygen-containing fuel. The difference concerns only the number of determined quantities and, therefore, the number of equations. So the composition of hydrocarbon fuels is determined only by two quantities $b_{\mathrm{C}}$ and $b_{\mathrm{H}}$ in the conditional fuel formula $\mathrm{C}_{b c} \mathrm{H}_{b c}$, and oxygen-containing hydrocarbon fuel - three: $b_{\mathrm{C}}, b_{\mathrm{H}}, b_{\mathrm{O}}$ in the conditional formula $\mathrm{C}_{b c} \mathrm{H}_{b c} \mathrm{O}_{b o}$. Let us analyze the possible reasons for the instability of the solution.

The solution method used in [5-7] is most commonly used in engineering calculations - the Newton-Rafson method. In the process of finding the causes of instability, the system of linear equations 
formed during linearization of the original nonlinear system was analyzed in the solution process. The calculation of the determinant of its principal matrix in all the cases considered gave a finite value. This shows that the system does not degenerate, that is, it has a solution and the model is correct.

To determine the cause of the instability of numerical search when solving the original nonlinear system of equations, let us consider the conditionality of the matrix of a linearized system, which characterizes the sensitivity of its solution to small changes in the coefficients. It was concluded in [8] that the determinant close to zero of the matrix $\mathbf{A}(\operatorname{det}(\mathbf{A}))$ indicates its poor conditionality. The value of the condition of the matrix $\mathbf{A}(\operatorname{cond}(\mathbf{A}))$ is a much more significant estimate of the solution of the linear system $\mathbf{A} x=b$ than the value of $\operatorname{det}(\mathbf{A})$, close to zero, or of large order $n$.

Number of square matrix conditionality:

$$
\operatorname{cond}(\mathbf{A})=\|\mathbf{A}\| \mathbf{A}^{-1} \|,
$$

here $\|\mathbf{A}\|$ and $\left\|\mathbf{A}^{-1}\right\|$ are the norms of the original linearized basic matrix of the system of equations and inverses, respectively.

The number of conditionality of the matrix depends on the choice of norm. But if the matrix is well conditioned, then its number of conditionality will be small in any choice, and if it is poorly conditioned, then its number of conditionality will be large in any choice of norm. In practice, the most widely used 1-norm, 2-norm and $\infty$-norm. The $\infty$-norm was chosen for the calculations, which defines as the maximum sum of modules of elements of each of the rows of the matrix:

$$
\|\mathbf{A}\|_{\infty}=\max _{1 \leq i \leq n} \sum_{j=1}^{n}\left|a_{i j}\right| \text {. }
$$

In the calculated embodiment, the number of conditionality is defined as:

$$
\operatorname{cond}(\mathbf{A})=\|\mathbf{A}\|_{\infty}\left\|\mathbf{A}^{-1}\right\|_{\infty} \text {. }
$$

Essentially, conditionality estimates the proximity of the coefficient matrix $\mathbf{A}$ to degeneracy. The condition number cond(A) is a quantitative estimate of conditionality. Note that always $\operatorname{cond}(\mathbf{A}) \geq 1$. If cond $(\mathbf{A}) \geq 10^{3}$, then matrix $\mathbf{A}$ is poorly conditioned. If $1 \leq \operatorname{cond}(\mathbf{A}) \leq 100$, then the matrix is considered well conditioned.

Two types of hydrocarbon fuel methane $\left(\mathrm{CH}_{4}\right)$ and oxygen-containing ethanol $\left(\mathrm{C}_{2} \mathrm{H}_{5} \mathrm{OH}\right)$ were considered. For each type of fuel, the solution of the forward and reverse problem was considered.

For the solutions of the direct problem we obtain a stable solution of the original systems of nonlinear equations. At the same time, it was not possible to get a sustainable solution for the variants of the inverse problem. The value of the conditionality of the matrices for each of the options is shown in Table 1.

For the considered variants, when solving the direct problem, the values of cond(A) are different, but the regularities are the same. The number of systems conditionality increases as we approach the solution. The reason for this is that as we approach the solution, the difference decreases between the previous approximation and the calculated current value. In this case, the influence of the error of calculation of the coefficients of the matrix of the system of equations, which was linearized, increases. The considerable value of cond(A) required the application of the lower relaxation coefficient (0.5) at each iteration to ensure the convergence of the computation process, which made it possible to obtain adequate solutions [5 - 7].

The situation is different for the inverse problem solution. The previously calculated values of cond(A) for the initial approximation were very large Table 1.

The large magnitudes of the conditionality numbers explain the lack of convergence of the solution for the inverse problem. As the calculations for the variants of the direct solution of the problem have shown, it is necessary to take into account an even larger increase in the values of cond(A) when iteratively approaching a stable solution. 
Comparison of calculations

\begin{tabular}{c|c|c|c|c}
\hline \multirow{2}{*}{ The type of task being solved by definition } & \multicolumn{3}{|c}{$\begin{array}{c}\text { The conditional numbers of the matrix cond(A) } \\
\text { for two types of hydrocarbon fuels }\end{array}$} \\
\cline { 2 - 5 } & \multicolumn{2}{|c}{$\begin{array}{c}\mathrm{CH}_{4} \\
\text { initial } \\
\text { approximation }\end{array}$} & Solution & \multicolumn{2}{|c}{$\begin{array}{c}\text { initial } \mathrm{C}_{2} \mathrm{H}_{5} \mathrm{OH} \\
\text { approximation }\end{array}$} & Solution \\
\cline { 2 - 5 } $\begin{array}{c}\text { The temperature of the products of com- } \\
\text { bustion of gases with a known composition } \\
\text { of the fuel in the measured parameters - } \\
\text { the ratio of costs (direct) }\end{array}$ & 540 & 1390 & 73 & 230 \\
\hline $\begin{array}{c}\text { The composition of the fuel in the meas- } \\
\text { ured parameters - the ratio of fuel con- } \\
\text { sumption and air, and the temperature of } \\
\text { the combustion products (reverse) }\end{array}$ & 5200 & & & \\
\hline
\end{tabular}

Based on the above definition of the conditionality of the linearized system of equations, a comparison of two variants of the initial data was carried out, the results of which are presented in Table 1.

The poor conditionality of the linearized systems of equations used in the iterative process of solving the original systems of nonlinear equations reflects the high sensitivity of the approximations. The problem can be solved by improving the accuracy of the initial approximations. Moreover, the greater the value of the number of conditioned matrix, the more accurate should be the initial approximation of certain quantities, which are the partial pressures of combustion products and the number of atoms of chemical elements in the conditional fuel formula. But the source data to solve this problem does not allow you to do this. The number of atoms in the process of decoupling may vary, which is unpredictable. The above calculations are for fuels consisting of no more than three chemical elements $\mathrm{C}_{b c} \mathrm{H}_{b c} \mathrm{O}_{b o}$. Therefore, you must use the library method to solve the inverse problem.

\section{A way to fill a library when solving a direct task}

The library is filled with solutions of a direct problem of 6 dimensions. This is the number of atoms of the corresponding elements in the gross fuel formula $\left(b_{\mathrm{C}}, b_{\mathrm{H}}, b_{\mathrm{O}}, b_{\mathrm{N}}\right)$, the coefficient of excess air $\alpha$ and the enthalpy of the fuel $I_{t}$.

The size of the interval of each of the six values can be any. For certainty, we take 100, which will allow you to track the change in each of the values $b_{\mathrm{C}}, b_{\mathrm{H}}, b_{\mathrm{O}}, b_{\mathrm{N}}$, for example, in the range of $0.05 . . .4 .95$ in increments of 0.05 , the values of $\alpha$ - in the range of $0.025 \ldots 2,5$ in increments of 0.025 . This requires $(100)^{6}=10^{12}$ solutions of the direct problem with fixation of all results, but reduction of the dimensionality of the problem is possible.

If nitrogen $(\mathrm{N})$ is introduced into the fuel only from the air, then the value of $b_{\mathrm{N}}$ from the variable list is excluded and will be quantitatively calculated by the coefficient of excess of oxidant $\alpha$. Further, according to [9], the number of variables in a problem can be reduced by normalizing them. There is no need to know its gross formula to implement a rational, or more widely controlled, fuel combustion process. It is enough to determine the ratio of the number of atoms of the chemical elements that make up it. For example, a process of combustion of ethane passing stoichiometrically can be created, both on the basis of its complete formula and at the normalized number of atoms:

$$
2 \mathrm{C}_{2} \mathrm{H}_{6}+7 \mathrm{O}_{2}=4 \mathrm{CO}_{2}+6 \mathrm{H}_{2} \mathrm{O} \text {, }
$$

or

$$
4 \mathrm{C}_{1} \mathrm{H}_{3}+7 \mathrm{O}_{2}=4 \mathrm{CO}_{2}+6 \mathrm{H}_{2} \mathrm{O} \text {. }
$$

The normalization is performed by the number of carbon atoms. In a gross formula, the number of atoms need not necessarily be integers. In this problem, the number of carbon atoms will be constant and equal to 1 . In this case, the gross formula is defined as:

$$
\mathrm{C}_{1} \mathrm{H}_{\left(b_{\mathrm{H}} / b_{c}\right)} \mathrm{O}_{\left(b_{\mathrm{o}} / b_{c}\right)} \mathrm{N}_{\left(b_{\mathrm{N}} / b_{c}\right)} \text { or } \mathrm{C}_{1} \mathrm{H}_{d_{\mathrm{H}}} \mathrm{O}_{d_{\mathrm{O}}} \mathrm{N}_{d_{\mathrm{N}}} \text {. }
$$


As a result, the number of solutions to the direct problem is reduced to $(100)^{4}=10^{8}$ variants. Consider a method of converting the results obtained into a form that is convenient to find solutions based on technological measurements of combustion products temperature and volumetric fuel and oxidizer costs.

1. Partial volume of calculation results in solving the direct problem are the partial pressures of gases in the mixture of combustion products. They do not take part in determining the composition of the source fuel and are not present in the library.

2. By varying $d_{\mathrm{H}}, d_{\mathrm{O}}, d_{\mathrm{N}}$ from (1), for each variant of solving a direct problem, a specific fuel composition is given and the molar stoichiometric ratio of the components $\chi_{0}$ is calculated. Taking into account [5-7] $\chi=a \chi_{0}$ and $\chi=\dot{V}_{o x} / \dot{V}_{f}$ and the change in the value of the coefficient of excess oxidizer $\alpha$ is converted into a change in the ratio of the measured technological parameters $\dot{V}_{o x} / \dot{V}_{f}$.

3. For all possible combinations of the initial data $\dot{V}_{o x} / \dot{V}_{f}(\alpha), d_{\mathrm{H}}, d_{\mathrm{O}}, d_{\mathrm{N}}$ and $I_{t}$, which occur when these quantities are varied, the direct problem of determining the temperature of the combustion products is solved. In some cases, the ratio of the composition of the fuel to its enthalpy is incompatible from the physical point of view. Such solutions are excluded from consideration.

4. For all existing solutions of a direct problem, the set of output data $d_{\mathrm{H}}, d_{\mathrm{O}}, d_{\mathrm{N}}$ and $I_{t}$ are written in the normalized form example,

$$
\bar{d}_{\mathrm{H}}=\frac{d_{\mathrm{H}}-d_{\mathrm{H}}^{l}}{d_{\mathrm{H}}^{r}-d_{\mathrm{H}}^{l}} \cdot 100,
$$

were $d_{\mathrm{H}}$ - is the number of hydrogen atoms in this implementation of the direct problem;

$d_{\mathrm{H}}^{l}, d_{\mathrm{H}}^{r}$ - left and right boundaries of the considered interval of change in the amount of hydrogen atoms when solving a direct problem.

In this case, the factor " 100 " corresponds to the number of steps of changing $d_{\mathrm{H}}$. Its value is due only to the selected range (0...4.95) and step (0.05) of change. As a result $\bar{d}_{\mathrm{H}} \in[00 \ldots 99]$. Similarly, $d_{\mathrm{O}}, d_{\mathrm{N}}$ and $I_{t}$ are converted to obtain the corresponding values $\bar{d}_{\mathrm{O}}, \bar{d}_{\mathrm{N}}$ and $\bar{I}_{t}$, whose values also change in the same or similar interval.

The obtained values are combined into a single number " $E_{k}$ " on the basis of the positional principle of the representation of decimal numbers by setting the values found to their corresponding digits (Fig. 1). It was decided to place values in the first two digits for certainty. Although the order of formation of this number may be any other. As a result, complexes are formed in which each pair of values of the results of the solution of a direct problem ( $T$ and $\dot{V}_{o x} / \dot{V}_{f}$ ) corresponds to a single number in which the values of the corresponding output data are collapsed;

5. The calculation results $\left(T\right.$ and $\left.\dot{V}_{o x} / \dot{V}_{f}\right)$ are structured as follows.

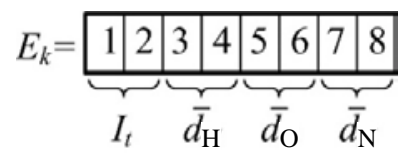

Fig. 1. View and diagram of the positional representation of a single number of normalized values of the initial data $\operatorname{Max}\left[T\right.$, $\left.\left(\dot{V}_{o x} / \dot{V}_{f}\right)^{r}\right]$ and $\min \left[T^{l},\left(\dot{V}_{o x} / \dot{V}_{f}\right)^{l}\right]$ values are determined. Their ranges are broken into several intervals. The number of intervals and, accordingly, the magnitude of the step of change of each magnitude is determined by the available technological accuracy of measuring the magnitudes ( $T$ and $\dot{V}_{o x} / \dot{V}_{f}$ ) in the process of burning the fuel.

6. Using the results of the solution ( $T$ and $\dot{V}_{o x} / \dot{V}_{f}$ ) of the direct problem and the corresponding initial data, summarized in a single number " $E_{k}$ ", a three-dimensional array is formed (Fig. 2). Plane $T-$ $\dot{V}_{o x} / \dot{V}_{f}$ is divided into cells with sides:

$$
\Delta T=\frac{T^{r}-T^{l}}{N} ; \Delta V=\frac{\left(\dot{V}_{o x} / \dot{V}_{f}\right)^{\mathrm{r}}-\left(\dot{V}_{o x} / \dot{V}_{f}\right)^{l}}{M},
$$

were $N, M$ is the number of elements (intervals) along the respective axes.

The cell boundaries are determined by the ratios: 


$$
\begin{gathered}
T_{i}^{l}=T^{l}+\Delta T \cdot(i-1) ; T_{i}^{r}=T^{r}+\Delta T \cdot i ; \quad i \in[0, N] . \\
\left(\dot{V}_{o x} / \dot{V}_{f}\right)_{j}^{l}=\left(\dot{V}_{o x} / \dot{V}_{f}\right)^{l}+\Delta V \cdot(j-1) ; \\
\left(\dot{V}_{o x} / \dot{V}_{f}\right)_{j}^{r}=\left(\dot{V}_{o x} / \dot{V}_{f}\right)^{r}+\Delta V \cdot j ; \quad j \in[0, M],
\end{gathered}
$$

where $i, j$ are the cell numbers along the $T$ and $\dot{V}_{o x} / \dot{V}_{f}$ axes respectively

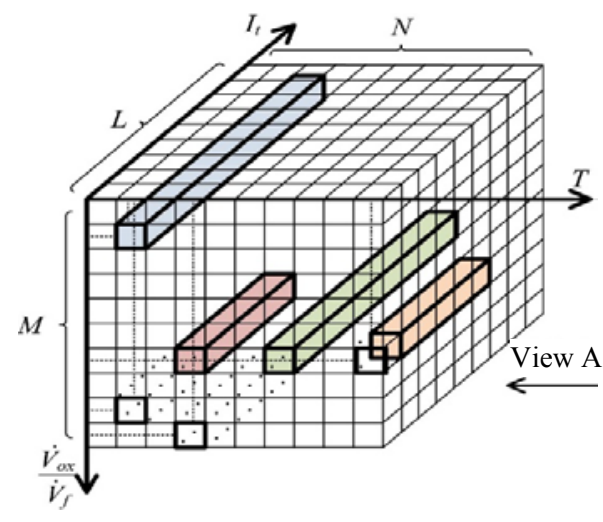

Fig. 2. Scheme of formation, structured working three-dimensional array of

"ibrary" on the basis of initial data and results of the solution of the direct problem

7. Each cell is assigned a vector of dimension $L$ (Fig. 2), the elements of which are the numbers " $E_{k}$ ". The value of the number is determined by the value in the first (highest) category. In this case, the values in the first digits are determined by the value of the enthalpy. Therefore, the vector axis is denoted as the enthalpy axis $I_{t}$. The step of changing the magnitude of the elements from the vector is determined in the same way (2) as for $T$ or $\dot{V}_{o x} / \dot{V}_{f}$ :

$$
\Delta I_{t}=\frac{I_{t}^{r}-I_{t}^{l}}{L},
$$

and the range of enthalpy change corresponding to each of the elements of the vector is determined from ratios similar to (3) or (4):

$$
\left(I_{t}^{l}\right)_{k}=I_{t}^{l}+\Delta I_{t} \cdot(k-1) ; \quad\left(I_{t}^{r}\right)_{k}=I_{t}^{r}+\Delta I_{t} \cdot k ; k \in[0, L],
$$

were $I_{t}^{l}, I_{t}^{r}-$ the minimum and maximum value of enthalpies from the considered range of their changes when solving a direct problem;

$\Delta I_{t}$ - Enthalpy change step; $L$ is the number of elements into which the enthalpy change interval is considered.

The values of $L, M$ and $N$ are determined taking into account the required accuracy of consideration of the corresponding quantities. Suppose, for example, that in the six considered values $N=100$ and $M=100$. In this case, $10^{4}$ cells are formed on the plane $T-\dot{V}_{o x} / \dot{V}_{f}$. In the number of implementations of the solution of the direct problem, the results of $\sim 10^{8} / 10^{4}=10^{4}$ solutions can correspond to each of the $10^{8}$ cells. A similar number of related " $E_{k}$ " solutions are placed in the elements of the corresponding vectors.

8. In the elements of the vector are placed the values " $E_{k}$ ", which are within their respective boundaries:

$$
E_{k} \in\left[\left(I_{t}^{l}\right)_{k},\left(I_{t}^{r}\right)_{k}\right] .
$$

Some elements of vectors are unfilled, because not all combinations of fuel composition $\left(\bar{d}_{\mathrm{H}}, \bar{d}_{\mathrm{O}}, \bar{d}_{\mathrm{N}}\right)$ can be realized in the considered list of enthalpy values $I_{t}$. The elements of the vectors are ordered in ascending order. Therefore, the values of the numbers " $E_{k}$ " within each vector are also ordered in ascending order. Examples of filling some vectors are shown in Fig. 2 and marked in color.

Thus, based on the solution of direct problems and processing of calculation results, a working three-dimensional array "library" is formed. Array values can be used to determine the composition of different fuels. It is important that their gross formula consists of the chemical elements used in forming the working array. However, some elements may be missing. For example, the considered array can serve as a basis for determining the composition of both oxygen-containing and oxygen-free hydrocarbons when they are combusted in the air (taking into account nitrogen) and in oxygen.

\section{Modeling of technological measurements without errors}

The proposed method of finding a solution to the inverse problem of interpretation based on the use of library data was tested for adequacy according to the previously known composition of gases: 
methane $\left(\mathrm{CH}_{4}\right)$, propane $\left(\mathrm{C}_{3} \mathrm{H}_{8}\right)$ and ethyl alcohol $\left(\mathrm{C}_{2} \mathrm{H}_{5} \mathrm{OH}\right)$. For methane, the rational, gross formula and the given gross formula are the same. For propane, the rational and the gross formulas are the same. The above gross formula looks like $\mathrm{CH}_{8 / 3}$ or $\mathrm{CH}_{2,(6)}$. For alcohol, the gross formula and the given gross formula are $\mathrm{C}_{2} \mathrm{H}_{6} \mathrm{O}$ and $\mathrm{CH}_{3} \mathrm{O}_{0.5}$, respectively. An example of combustion of these substances in oxygen was considered. This allows you to use the gross formula of the formula to search for fuel composition:

$$
\mathrm{CH}_{\overline{d_{\mathrm{H}}}} \mathrm{O}_{\overline{d_{\mathrm{O}}}} \text {. }
$$

This choice for checking the adequacy of the method is due to the following reasons:

- the use of air as an oxidizing agent does not introduce in the process of combustion fundamental features in comparison with the use of oxygen. The absence of nitrogen makes the method work test less voluminous;

- the choice of alcohol as fuel is due to the availability of reference data [10] on the process of its combustion in oxygen ( $\alpha, T$, the composition of combustion products). This provides control over the reliability of the results of solving a direct problem when forming a working three-dimensional array;

- fulfillment of the requirement of finding the fuel in the gaseous state for alcohol is ensured by considering the case of finding it in the vapor state and the corresponding enthalpy state.

The initial data of technological measurements were simulated by the results of solving a direct problem for the corresponding substances. Two variants of the initial data assignment were considered.

1. Simulation of technological measurements without taking into account measurement errors. The purpose is to verify the operational efficiency of the proposed method. The coincidence or deviation of certain compositions of combustible from the specified will determine the calculated error of the method.

2. Simulation of technological measurements with the introduced measurement error. The purpose is to evaluate the effect of measurement error on the accuracy of determining the composition of the fuel.

The option of specifying the output does not affect the order of formation of a working threedimensional array. The following ranges of change were made to the original data:

- in (5)

$$
\begin{array}{llll}
\exists \bar{d}_{\mathrm{H}} \in[0 \ldots 4.95]: & \left(\bar{d}_{\mathrm{H}}\right)_{i}=\Delta d(i-1) & \Delta d=0.05 & \forall i \in[1 \ldots 100], \\
\exists \bar{d}_{\mathrm{O}} \in[0 \ldots 4.95]: & \left(\bar{d}_{\mathrm{O}}\right)_{i}=\Delta d(i-1) & \Delta d=0.05 & \forall i \in[1 \ldots 100] ;
\end{array}
$$

- oxidizer excess coefficient $\alpha$ :

$$
\exists \alpha \in[0.025 \ldots . .2 .5]: \quad \alpha_{i}=0.025+\Delta \alpha(j-1) \quad \Delta \alpha=0.025 \quad \forall j \in[1 \ldots 100] .
$$

- enthalpy of fuel $I_{t}$ :

$$
\exists I_{t} \in[-13500 \ldots 8800] \frac{\mathrm{kJ}}{\mathrm{kg}}: \quad\left(I_{t}\right)_{i}=-13500+\Delta I_{t}(i-1) \quad \Delta I_{t}=100 \quad \forall i \in[1 \ldots 224] .
$$

As a result, the solutions of the direct problem were found to be $2.2410^{8}$. For all combinations of the initial data, the temperatures of combustion products were calculated and the coefficients of excess oxidizer $\alpha$ relative to the volumetric flow rates of oxidizer and fuel $\dot{V}_{o x} / \dot{V}_{f}$. were used. $\sim 2.7 \mathrm{~GB}$ of memory. After being converted to binary, the volume is reduced to $1.2 \mathrm{~GB}$.

Further, based on the solution of the direct problem, exact measurements of technological parameters $\left(\dot{V}_{o x} / \dot{V}_{f}\right.$ and $\left.T_{i}\right)$ were simulated. Using the obtained values from the previously formed working array, the solutions of the inverse problem were determined. The results of the calculations are given in Table. 2. The third column shows the exact normalized gross formulas of the corresponding substances with the given values of the quantities of the corresponding atoms. The fourth column shows similar formulas, but with the calculated values of atoms. 
Normalized calculated and accurate gross formulas with given values of the number of atoms

\begin{tabular}{c|c|c|c}
\hline $\begin{array}{c}\text { Rational } \\
\text { formula }\end{array}$ & $\begin{array}{c}\text { Normalized } \\
\text { gross formula }\end{array}$ & $\begin{array}{c}\text { Normalized gross formula with } \\
\text { the exact value of the number of } \\
\text { atoms }\end{array}$ & $\begin{array}{c}\text { Normalized gross formula with } \\
\text { the given number of atoms } \\
\text { resolved }\end{array}$ \\
\hline $\mathrm{CH}_{4}$ & $\mathrm{CH}_{4}$ & $\mathrm{CH}_{4}$ & $\mathrm{CH}_{4}$ \\
\hline $\mathrm{C}_{3} \mathrm{H}_{8}$ & $\mathrm{CH}_{2.67}$ & $\mathrm{CH}_{2.67}$ & $\mathrm{CH}_{2.67}$ \\
\hline $\mathrm{C}_{2} \mathrm{H}_{5}(\mathrm{OH})$ & $\mathrm{CH}_{3} \mathrm{O}_{0.5}$ & $\mathrm{CH}_{3} \mathrm{O}_{0.5}$ & $\mathrm{CH}_{3} \mathrm{O}_{0.5}$ \\
\hline
\end{tabular}

The use of the proposed method in determining the composition of the fuel allowed for the substances (methane, propane, ethyl alcohol) to obtain accurate within the model solution. When determining the composition of methane in the case of one hundred interval intervals, the number of hydrogen atoms found was always 4.

The calculated error can only be due to the degree of discretization of the raw data. In the case of a reduction of the partition interval by four times, the number of hydrogen atoms was determined taking into account the calculated error and was in the range [3.95...4.05] for methane. The ambiguity range in this case is due only to the sampling step (6) of this magnitude in solving the direct problem. No other calculations were made on this basis.

\section{Conclusions}

1. Determined the general type of the problem, as inversely incorrectly assigned and distinguished its narrower class - a difficult task of interpretation.

2. The method of filling the library with the solutions of a direct problem in the form of a working three-dimensional array is developed. For this purpose, a method of converting the initial data of a direct problem into a convolution number (the number of atoms of chemical elements in the gross formula and the enthalpy of fuel) is proposed, which is formed on the basis of the positional principle of writing decimal numbers.

3. The absence of errors that are brought to the decision by the algorithm of the proposed method is shown. When modeling accurate technological measurements, the calculation errors are only due to the discretization of the output data when solving a direct problem.

4. The influence of measurement accuracy of technological parameters on the uncertainty of the fuel composition determination is determined. The magnitude of the error does not exceed the allowable value for engineering calculations.

\section{Література}

1. Dou Z., Sun L. Design of Temperature Controller for Heating Furnace in Oil Field. International Conference on Applied Physics and Industrial Engineering. Physics Procedia. 2012. 208 p.

2. Способ автоматической оптимизации процесса сжигания топлива переменного состава: пат. RU 2647940 Россия: F23C1/02; заявл. 04.05.2017; дата регистрации 21.03.2018.

3. Pitel’ J., Mizáková J., Hošovský A. Biomass Combustion Control and Stabilization Using Low-Cost Sensors. Advances in Mechanical Engineering. 2013, Article ID 685157. 7 p.

4. Morales S.A., Barragan D.R., Kafarov V. 3D CFD Simulation of Combustion in Furnaces Using Mixture Gases with Variable Composition. Chemical Engineering Transactions. 2018. Vol. 70. P. 121-126.

5. Давыдов В.О., Бондаренко А.В. Метод расчета температуры горения произвольной смеси газообразного углеводородного топлива при произвольном избытке воздуха. Труды Одесского политехнического университета. 2013. Вып. 3 (42). С. 98-102.

6. Determining the composition of burned gas using the method of constraints as a problem of model interpretation / O. Brunetkin, V. Davydov, O. Butenko, G. Lysiuk, A.Bondarenko. Eastern-European Journal of Enterprise Technologies. 2019. Vol. 3 (6 (99)). P. 22-30. DOI: https://doi.org/10.15587/1729-4061.2019.169219.

7. Brunetkin O. I., Maksymov M. V., Maksymenko A., Maksymov M.M. Development of the unified model for identification of composition of products from incineration, gasification, and slow pyrolysis. 
Eastern-European Journal of Enterprise Technologies. 2019. Vol. 4 (6 (100)). P. 25-32. DOI: https://doi.org/10.15587/1729-4061.2019.176422.

8. Форсайт Дж., Молер К. Численное решение систем линейных алгебраических уравнений. Мир. 1969. $168 \mathrm{c.}$

9. Maksymov M.V, Brunetkin O.I., Maksymova O.B. Application of a Special Method of nondimensionization in the solution of nonlinear dynamics problems control systems: theory and applications. series in automation, control and robotics river publishers. Alsbjergvej. 2018. Chapt. 5. P. 97-144.

10. Термодинамические и теплофизические свойства продуктов сгорания: справочник. Т. 3: Топлива на основе кислорода и воздуха. ВИНИТИ. 1973. 624 с.

\section{References}

1. Dou, Z., \& Sun, L. (2012). Design of Temperature Controller for Heating Furnace in Oil Field. International Conference on Applied Physics and Industrial Engineering. Physics Procedia.

2. A method for automatically optimizing the process of burning fuel of variable composition (2018). Patent RU 2647940 Russia: F23C1/02.

3. Pitel’, J., Mizáková, J., \& Hošovský, A. (2013). Biomass Combustion Control and Stabilization Using Low-Cost Sensors. Advances in Mechanical Engineering, Article ID 685157.

4. Morales, S.A., Barragan, D.R., Kafarov, V. (2018). 3D CFD Simulation of Combustion in Furnaces Using Mixture Gases with Variable Composition. Chemical Engineering Transactions, 70, 121-126.

5. Davydov, V.O., \& Bondarenko, A.B. (2013). Method for calculating the combustion temperature of an arbitrary mixture of gaseous hydrocarbon fuel with an arbitrary excess of air. Proceedings of Odessa Polytechnic University, 3 (42), 98-102.

6. Brunetkin, O., Davydov, V., Butenko, O., Lysiuk, G., \& Bondarenko, A. (2019). Determining the composition of burned gas using the method of constraints as a problem of model interpretation. EasternEuropean Journal of Enterprise Technologies, 3 (6 (99), 22-30. DOI: https://doi.org/10.15587/17294061.2019.169219.

7. Brunetkin, O. I., Maksymov, M. V., Maksymenko, A., \& Maksymov, M.M. (2019). Development of the unified model for identification of composition of products from incineration, gasification, and slow pyrolysis. Eastern-European Journal of Enterprise Technologies, 4 (6 (100)), 25-32. DOI: https://doi.org/10.15587/1729-4061.2019.176422.

8. Forsyth, J., \& Moler, K. (1969). Numerical solution of systems of linear algebraic equations. Mir.

9. Maksymov, M. V, Brunetkin, O.I., \& Maksymova, O.B. (2018). Application of a Special Method of nondimensionization in the solution of nonlinear dynamics problems. control systems: theory and applications. series in automation, control and robotics. river publishers. Alsbjergvej, 5, 97-144.

10. Thermodynamic and thermophysical properties of combustion products: reference book. (1973). T. 3: Oxygen and air based fuels. VINITI.

Бутенко Олександр Валерійович; Butenko Oleksandr, ORCID: https://orcid.org/0000-0003-1267-3002

Демиденко Володимир Едуардович; Demydenko Volodymyr

Брунеткін Олександр Іванович; Brunetkin Oleksandr, ORCID: https://orcid.org/0000-0002-6701-8737 